\title{
PRÓBY POWOlANIA BIALORUSKIEJ POLITYCZNEJ REPREZENTACJI NARODOWEJ W CZASIE PIERWSZEJ WOJNY ŚWIATOWEJ I BEZPOŚREDNIO PO JEJ ZAKOŃCZENIU
}

\author{
ATTEMPTS TO ESTABLISH A BELARUSIAN NATIONAL POLITICAL \\ REPRESENTATION DURING AND IMMEDIATELY \\ AFTER THE FIRST WORLD WAR
}

The onset of a modern idea of Belarusian statehood coincides with the period of the end of the First World War. It was a particularly difficult time for Belarusian lands: the front, which divided the country into two parts for a long time; the scorched-earth policy employed by the Russians; mass requisitions carried out by both armies, war destruction and recruitment drainage all contributed to the ongoing economic and demographic collapse of Belarus. The proclamation of independence of the Belarusian People's Republic on 25 March 1918 turned out to be a short-lived success. As a territorial entity, the young state survived only until December that year. The challenges which the supporters of the country's independence had to face between 1918 and 1919 surpassed capabilities and organizational skills of the movement. It also seems that the pace of development and the nature of geopolitical challenges were beyond the abilities of the Belarusian elite.

Słowa kluczowe: Białoruś, niepodległość, Białoruska Republika Ludowa, wojna, tożsamość narodowa, polityka narodowościowa

Key words: Belarus, independence, Belarusian People's Republic, war, national identity, national policy

* Dr hab. Jacek Reginia-Zacharski, Uniwersytet Łódzki, jrz2@wp.pl, https://orcid.org/0000-0002-1939-1246

arodziny nowoczesnej państwowości białoruskiej trzeba wiązać ze schył-
kiem pierwszej wojny światowej. Dla ziem białoruskich był to czas wyjątkowo trudny. Front, który na długi czas podzielił kraj na dwie części, stosowana przez Rosjan „taktyka spalonej ziemi”, masowe rekwizycje prowadzone przez obie armie, zniszczenia wojenne i rekrutacyjny drenaż zasobów ludzkich ${ }^{1}$ spowodowały postępującą zapaść gospodarczo-demograficzną Białorusi. Towarzyszący działaniom wojennym strach potęgujący wspomniane zjawiska doprowadził do ucieczki ponad dwóch milionów mieszkańców. Chroniczność działań wojennych, zmniejszająca się liczba ludności spowodowały, że aby sięgnąć do rezerw zarówno Niemcy, jak i Rosjanie z uwagą i niekiedy koniunkturalną sympatią zaczęli się odnosić do inicjatyw lokalnych, odwołujących się do eksplikowanych aspiracji narodowościowych.

${ }^{1}$ Vide W. Churchill, The Unknown War. The Eastern Front 1914-1917, London 1941, s. 353. 
Sytuacja zaczęła przyspieszać po wielkich ofensywach rosyjskich z $1916 \mathrm{r}^{2}$ Nie przyniosły one żadnych rozstrzygnięć, natomiast wykazały, że armia rosyjska nie była zdolna do działań dających nadzieję na przejęcie inicjatywy strategicznej. Pod koniec 1916 r. rosyjskie wojsko było właściwie zdolne do utrzymywania linii frontu, choć i to zadanie stało pod znakiem zapytania ${ }^{3}$. Rewolucja lutowa w 1917 r. pogłębiła jeszcze to rozprzęgnięcie. Na całym froncie i na zapleczu powstawały narodowe ,koła wojskowe", od których o krok było od sformułowania postulatów politycznych. Warto zauważyć, że gdy już zaczęły się pojawiać, nie wykraczały poza autonomię w ramach sfederowanego państwa ${ }^{4}$.

$\mathrm{Na}$ ziemiach białoruskich podzielonych frontem zaczęły się procesy emancypacyjne. Zarówno wojskowe władze niemieckie, jak i rosyjskie z dużą otwartością podchodziły do aspiracji narodowościowych, zakładając, że ich realizacja nie będzie zbyt wysoką ceną za wsparcie wysiłku wojennego. Należy nadmienić, że strona niemiecka była szczególnie zmotywowana z powodu postępującej zapaści gospodarczej. Zarówno w Berlinie, jak Wiedniu zimą 1916/1917 pojawiły się pierwsze oznaki głodu ${ }^{5}$. Z pewnością przyczyniało się do zwiększenia zainteresowania Niemców lokalnymi inicjatywami polityczno-społecznymi, które mogły zagwarantować wsparcie dla wysiłku wojennego na wschodzie.

Rewolucja lutowa w Rosji zauważalnie zdynamizowała sytuację w zachodnich częściach imperium Romanowów. Obalenie caratu i utworzenie Rządu Tymczasowego z księciem Gieorgijem Jewgienjewiczem Lwowem na czele dość powszechnie zostało odebrane jako zapowiedź rychłego zakończenia wojny. Ofensywa z lipca 1917 r. rozwiała te nadzieje, pogłębiając zniechęcenie i nieufność wobec władz centralnych ${ }^{6}$. Ustąpienie G. Lwowa i objęcie stanowiska premiera przez Aleksandra Kiereńskiego, dotychczasowego ministra wojny, radykalizowało antywojenne nastroje. Natomiast liberalny kurs Rządu Tymczasowego w kwestiach narodowościowych zaowocował pojawieniem się wielu inicjatyw politycznych, wśród których najpoważniejsze dotyczyły ziem ukraińskich?7. Również na Białorusi zauważalne było ożywienie społeczno-polityczne. Miało ono szczególne uwarunkowania wynikające przede wszystkim ze słabego skonsolidowania i poczucia tożsamości elit polityczno-społecznych, niskiej samoidentyfikacji społeczeństwa, braku zewnętrznych ośrodków wsparcia (nie było żadnego ośrodka, który można by nazwać „białoruskim Piemontem”), mało ostrego kryterium religijnego.

${ }^{2} \mathrm{~W}$ istocie ostatnią próbą przejęcia inicjatywy strategicznej była tzw. ofensywa Kiereńskiego z lipca 1917 r., jednak z wojskowego punktu widzenia nie miała ona dużych szans powodzenia. Należy ją traktować raczej jako polityczno-wojskową demonstrację „lojalności” wobec ententy.

3 H. Batowski, Rozpad Austro-Wegier 1914-1918, Warszawa 1982, s. 328.

4 E. Charaszkiewicz, Przebudowa Europy Wschodniej. Fragmenty faktów z lat 1917-1924, „Niepodległość" 1974, t. 9, s. 43.

${ }^{5}$ K. Fiedor, Niemcy i Austria po I wojnie światowej w 1919 roku, [w:] Rok 1918 w Polsce $i$ w państwach sasiednich. W osiemdziesięciolecie zakończenia pierwszej wojny światowej z perspektywy śląskiej, red. L. Kuberski, M. Lis, Opole 1998, s. 99.

6 I. Kershaw, Do piekła i z powrotem: Europa 1914-1949, Kraków 2016, s. 47-48.

7 J. Reginia-Zacharski, Sprawa ukraińska w polityce Wielkiej Brytanii w latach 1917-1923, Toruń 2004, s. 27-28. 


\section{TOŻSAMOŚĆ NARODOWA NA ZIEMIACH BIALORUSKICH U SCHYLKU I WOJNY ŚWIATOWEJ}

„Przebudzenie” białoruskiej idei narodowej przypadło na schyłek lat sześćdziesiątych XIX w. Wówczas na uniwersytetach imperium rosyjskiego (głównie w Petersburgu) zaczęły powstawać niewielkie koła studenckie odwołujące się do ludowości białoruskiej. Warto podkreślić, że ich sytuacja była szczególnie trudna. Jedno z pierwszych takich kół, kierowane przez Wojnisławicza Sawicz-Zabłockiego ${ }^{8}$, zostało rozbite, a jego członkowie skazani za polski separatyzm. Podobny los spotykał grupy ze szkół wyższych z Wilna i Kijowa. W latach osiemdziesiątych pojawily się pierwsze tytuły wydawane w języku białoruskim: „Minskij Listok” i „Homon”. Jednak prawdziwy przełom przyniosło pokolenie, które w dorosłość zaczęło wchodzić na przełomie stuleci. Co ciekawe, większość aktywistów tej fali odrodzenia (czy może lepiej „narodzenia”) narodowego stanowili przedstawiciele klas wyższych, nierzadko wywodzących się z kręgów polskiej bądź wcześniej spolonizowanej szlachty. Jednocześnie powstawały zręby białoruskich ruchów socjalistycznych i socjalizujących ${ }^{9}$. Nie będzie chyba przesadą, że białoruskie ożywienie narodowe charakteryzowało się swoistym przeplataniem nurtów politycznych (z silnym zaznaczeniem romantyczno-pozytywistycznego nacjonalizmu i socjalizmu), co było typowe dla tej części Europy. Równolegle powstało Koło Białoruskiej Oświaty i Kultury Narodowej i Białoruska Rewolucyjna Hromada, przekształcone w Białoruską Socjalistyczną Hromadę.

Istotnym rysem budowania zrębów politycznej i narodowej tożsamości białoruskiej była koncentracja na działalności wydawniczej i kulturalno-oświatowej. Ten kierunek utrzymujący się z powodzeniem do czasów I wojny światowej wyraźnie dominował nad działalnością stricte polityczną. Stało się to jednym z głównych powodów zaskakującej żywotności ruchu białoruskiego. Władze carskie, dostrzegając dominantę kulturową i społeczną w mniejszym stopniu niż w odniesieniu do ruchów politycznych, koncentrowały się na wysiłkach na rzecz jego zniszczenia. W ten sposób niemal bez większych przeszkód ziemie białoruskie w pierwszej dekadzie XX w. zostały „zmonopolizowane” przez dwie gazety — „Naszą Niwę” i (w nieco mniejszym stopniu) katolicką „Białoruś”. Wilno stało się centrum wydawniczego ruchu białoruskiego, co w przyszłości miało odegrać istotną rolę.

Wraz z narastaniem świadomości wśród elit białoruskich doszło również do konceptualizacji głównych kierunków działań. Na pierwszy plan wysunęły się kwestie edukacyjne, co zresztą znalazło swoje odbicie na łamach „Naszej Niwy”. Początki szkolnictwa białoruskiego należy wiązać z 1906 r. Wtedy w Stróżówce (powiat ihumeński) otwarta została pierwsza szkoła. Ten uruchomiony stosunkowo późno, „pozytywistyczny" ogląd rzeczywistości bazował na przekonaniu, że chociaż istniały stosunkowo solidne (jak na warunki białoruskie) twórcze elity narodowościowe, to ich kontakt ze

${ }^{8}$ A. Czerniakiewicz, ,, Chto tam idzie?” Kryzys białoruskiego projektu kulturowego na progu pierwszej wojny światowej, [w:] Imperia, narody i społeczeństwa Europy Środkowej $i$ Wschodniej na progu pierwszej wojny światowej, red. A. Nowak, Warszawa 2016, s. 47

9 Ibidem, s. 49-50. 
społeczeństwem był znikomy. Programy społeczno-polityczne promujące rozwój szkolnictwa białoruskiego, co warto odnotować, nie padły na szczególnie podatny grunt. Napotykały dość silny opór kół inteligencji białoruskiej, w tym nauczycieli ${ }^{10}$. Silne wpływy rosyjskie (także w szkolnictwie) postrzegane były jako skuteczna przeciwwaga dla prężnego żywiołu polskiego. Odzew białoruskiego chłopstwa na edukacyjne inicjatywy inteligenckich kręgów był co najmniej wstrzemięźliwy. Narodowa idea białoruska postrzegana była niejednokrotnie jako konkurencyjna w stosunku do rozwijającej się emancypacji gospodarczej (i majątkowej) wsi białoruskiej. Kwestie społeczne i narodowościowe na ziemiach białoruskich ujmowane były w nieco tautologicznej formule: „Białorusin może być wyłącznie chłopem, a chłop Białorusinem”"11. W takiej atmosferze inteligencja białoruska często stawała się obiektem oskarżeń o ,propagowanie polonizacji” z jednej strony, lub „tendencje rusofilskie” z drugiej.

Odpowiedzią na te dylematy miał być program Towarzystwa Białoruskiego, który jednak nie wychodził poza postulaty autonomii w ramach państwa rosyjskiego. Wskazywano na wspólnotę z „Wielkorusinami i Małorusinami”, a radykałów z „Naszej Niwy" przestrzegano przed separatyzmem. Ostatecznie Towarzystwo działające od 1908 r. u progu Wielkiej Wojny znalazło się na pozycjach prorosyjskich, choć zaznaczały się w myśli politycznej tych kół dość wyraźnie eksplikowane tendencje republikańskie i autonomiczne ${ }^{12}$.

Warte odnotowania jest, że nadchodząca wojna budziła $z$ jednej strony istotne nadzieje, z drugiej zaś - poważne obawy. Te pierwsze wynikały (podobnie jak w przypadku polskim) z dostrzegania szans dla realizacji postulatów narodowych, które mogły się pojawić. Drugie z uwarunkowań geograficznych ziem białoruskich, które w oczywisty sposób miały się stać teatrem zmagań militarnych między Rosją a Niemcami.

\section{BIALORUSINI WOBEC REWOLUCJI W ROSJI I WOJSK NIEMIECKICH NA WSCHODZIE}

Po zajęciu przez armie niemieckie części ziem białoruskich lokalne elity intelektualne początkowo raczej zachowały daleko idącą wstrzemięźliwość w rozwijaniu postulatów narodowych. Na przykład Iwan i Anton Łukiewiczowie z kręgów „Naszej Niwy” w kontaktach z niemieckimi władzami wojskowymi nie wysuwali postulatów idących dalej niż zagwarantowanie interesów ludności białoruskiej na okupowanych terenach ${ }^{13}$. Niektórzy badacze utrzymują, że pojawienie się wyartykułowanych aspiracji niepodległościowych w części było efektem inspiracji niemieckiej. Miało ono nastąpić po serii spotkań z radykalnymi kręgami inteligencji białoruskiej, które zrealizowano w Wilnie. Propozycja

${ }^{10}$ O. Łatyszonek, Od Rusinów Biatych do Białorusinów. U źródet białoruskiej idei narodowej, Białystok 2006, s. 299-301.

${ }^{11}$ Vide szerzej R. Radzik, Ksztaltowanie się nowoczesnej białoruskości w XX stuleciu, [w:] Biatoruś wXX stuleciu. W kręgu kultury i polityki, red. D. Michaluk, Torun 2007, s. 163-164.

12 A. Czerniakiewicz, op. cit., s. 52.

13 D. Michaluk, Białoruska Republika Ludowa 1918-1920. U podstaw białoruskiej państwowości, Toruń 2010, s. 107. 
utworzenia niepodległego państwa białoruskiego, pozostającego w ścisłym związku (właściwie w uzależnieniu) z Rzeszą wpisywała się w scenariusz wyłaniający się z koncepcji Mitteleuropy Friedricha Naumanna $(1915 \text { r. })^{14}$. Nie była to jednak idea szczególnie popularna. W $1915 \mathrm{r}$. wśród białoruskich aktywistów politycznych wyłonił się pogląd o „konieczności” restytucji Wielkiego Księstwa Litewskiego, w którym obok Białorusinów własne aspiracje na zasadach symetrii mieliby zagwarantowane Litwini, Polacy oraz Żydzi. Ostatecznie ten projekt ucieleśnił się w treści deklaracji z 19 grudnia $1915 \mathrm{r}^{15}$, w myśl której w przyszłości miała powstać Konfederacja Wielkiego Księstwa Litewskiego, gdzie Litwa i Białoruś miały być niepodległymi choć skonfederowanymi państwami. Jak wspomniano wcześniej, na ziemiach imperium rosyjskiego rozpad politycznego centrum postrzegany był raczej w kategoriach przewartościowania modelu państwowości niż jako ostateczne jej załamanie. Słabe i mało skonsolidowane elity polityczne z reguły nie wychodziły poza oczekiwania funkcjonowania w ramach federacji narodów ze znacznym stopniem autonomii. Na ziemiach białoruskich właśnie takie aspiracje zgłoszone zostały przez Białoruski Komitet Narodowy. Ukonstytuował się on w wyniku zjazdu wielu małych organizacji, jaki odbył się w Mińsku 25-27 marca (7-9 kwietnia) 1917 r. Na czele Komitetu stanął Roman Skirmunt. który był postrzegany jako zwolennik koncepcji federacji narodów Wielkiego Księstwa Litewskiego ${ }^{16}$. Na zjeździe marcowym wypowiedziano się za autonomią w ramach nowego państwa rosyjskiego, jednak plany rozpoczęcia negocjacji z Rządem Tymczasowym napotkały mur niechęci - Petersburg nie był zainteresowany aspiracjami Białorusinów. O słabości pozycji białoruskich aktywistów może świadczyć choćby zestawienie potraktowania ich aspiracji z oczekiwaniami ukraińskiej Centralnej Rady. O ile w odniesieniu do programu ukraińskiego Rząd Tymczasowy zajął stanowisko zdecydowanie negatywne, to przynajmniej aspiracje te zostały dostrzeżone. Natomiast apele zjazdu mińskiego przeszły właściwie bez echa. Rozgoryczenie i frustracja tym spowodowana doprowadziła do aktywizacji kół nastawionych bardziej radykalnie, przede wszystkim Białoruskiej Socjalistycznej Hromady [dalej: BSH]. W łonie tej organizacji doszło do wyraźnego pęknięcia. Część działaczy zaczęła się skłaniać w kierunku haseł bolszewickich i internacjonalistycznych. Aktywiści Hromady przywiązani do idei narodowych doprowadzili do zmiany w zarządzie BSH, w którym większość miejsc zajęli działacze „konserwatywni” z Jazepem Dyłą na czele. Pod auspicjami nowego zarządu jeszcze w październiku 1917 r. zwołano Centralną Radę Białoruskich Organizacji i Partii, która 15-16 (24-25) października przekształciła się w Wielką Radę Białoruską [dalej: WRB], a w której sporą reprezentację miały również ugrupowania o programach dalekich od socjalizmu. Polityczne aspiracje głoszone przez WRB nie wychodziły poza autonomię ziem białoruskich w ramach państwa rosyjskiego. W przyszłości WRB miała przekształcić się w rząd białoruski, co

${ }^{14}$ L. Moczulski, Geopolityka. Potega w czasie i przestrzeni, Warszawa 2010, s. 503-507.

15 D. Michaluk, Białoruska Republika Ludowa..., s. 135.

16 J. Gierowska-Kałłaur, Stanowisko Rady Polskiej Ziemi Mińskiej w kwestii przyszłości Białorusi. Przyczyny zmiany stanowiska Komisji Litewskiej Tymczasowej Rady Stanu na jesieni 1918 roku, [w:] Biatoruś w XX stuleciu. W kręgu kultury i polityki, red. D. Michaluk, Toruń 2007, s. 639-640. 
notabene stało się główną przesłanką dla prób pozyskiwania poparcia i udziału szerokiego spektrum społecznego i narodowościowego. W ramach WRB ukonstytuował się 24-osobowy Komitet Wykonawczy, który miał pełnić funkcje i zadania quasi-gabinetu. Natomiast w działaniach operacyjnych, szczególnie po włączeniu do WRB kół militarnych, określono również postulat formowania białoruskich oddziałów wojskowych, których zadaniem miało być utrzymanie odcinka frontu. Równolegle bowiem do obrad Centralnej Rady na przełomie października i listopada (nowego stylu) 1917 r. w Mińsku obradował zjazd wojskowych, identyfikujących się z białoruską ideą narodową, w skład którego weszli przedstawiciele Frontu Zachodniego, 12. Armii, Floty Bałtyckiej i Frontu Rumuńskiego. Efektem zjazdu było utworzenie Centralnej Białoruskiej Rady Wojskowej i decyzja o podporządkowaniu się WRB ${ }^{17}$.

Działania kół białoruskich trzeba uznać za mocno spóźnione - bezpośrednio po przewrocie, w listopadzie 1917 r. bolszewicy zorganizowali w Mińsku trzy zjazdy: Delegatów Chłopskich, Delegatów Robotniczych i Żołnierskich oraz Delegatów z Frontu ${ }^{18}$. Oczywistą konkluzją każdego z nich był postulat wprowadzenia na Białorusi władzy sowieckiej. Działo się to po błyskawicznym opanowaniu przez bolszewików samego Mińska i większości miast białoruskich ${ }^{19}$. Ograniczone sukcesy Rady Wojskowej w tworzeniu białoruskich oddziałów wojskowych paradoksalnie zostały zdyskontowane przez bolszewików, którzy dość łatwo je sobie podporządkowywali (warto pamiętać o wysokim stopniu zbolszewizowania mas żołnierskich u schyłku 1917 r.), powiększając tym samym swój potencjał. Pewną szansą dla narodowych kół białoruskich mogło być białorusko-polskie porozumienie w kwestii obrony przed naciskiem bolszewickim, zostało ono jednak zerwane przez stronę białoruską.

W dniach 5-17 (18-30) grudnia 1917 r. w gmachu Teatru Miejskiego w Mińsku odbył się I Zjazd (Kongres) Wszechbiałoruski, zorganizowany przez WRB za zgodą Ludowego Komisariatu ds. Narodowości. Na Zjeździe zostało zarejestrowanych ponad 1,8 tys. delegatów, reprezentujących różne środowiska i ugrupowania polityczne. W trakcie obrad zarysowało się wyraźne ,pęknięcie” w programach politycznych. O ile postulaty samostanowienia dla narodu białoruskiego i demokratycznej formy rządu nie budziły szczególnych kontrowersji wśród delegatów, to już ich realizacja wywołała burzliwą dyskusję. Zaznaczyła się pewna prawidłowość - delegaci z zachodnich obszarów ziem białoruskich opowiadali się za szeroką autonomią lub niepodległością, przedstawiciele okręgów wschodnich optowali raczej za ścisłym związkiem z „demokratyczną” Rosją. Mimo antagonizmów udało się wyłonić 71-osobową Radę Kongresu o szerokim spektrum politycznym, a następnie Komitet Wykonawczy Rady z Jazepem Waronką ${ }^{20}$.

${ }^{17}$ Starania o przerzucenie na białoruski odcinek frontu blisko 200 tys. żołnierzy białoruskich nie zostały zrealizowane. Podobnie zresztą jak inne projekty Rady Wojskowej. Ostatecznie została ona rozbita w styczniu 1918 r. przez bolszewików. O. Łatyszonek, Białoruskie formacje wojskowe 1917-1923, Białystok 1995, s. 110.

${ }_{18}$ D. Michaluk, Biatoruska Republika Ludowa..., s. 149.

19 R. Pipes, Rewolucja Rosyjska, Warszawa 1996, s. 194.

${ }^{20}$ D. Michaluk, Białoruska Republika Ludowa..., s. 182-187. 
Waronka, od rewolucji lutowej działacz Hromady, znany był jako zwolennik koncepcji autonomii $\mathrm{w}$ ramach federacji rosyjskiej. W okresie działania WRB pełnił funkcję komisarza sprawiedliwości i spraw wewnętrznych. Ostatniego dnia Kongresu bolszewicy zdecydowali się na jego rozpędzenie, pod pretekstem szerzenia nacjonalizmu. Komitet Wykonawczy Waronki ,zszedł do podziemia”.

Równolegle do wydarzeń w Mińsku w Brześciu Litewskim trwały przygotowania do rozpoczęcia rozmów pokojowych między dowództwem Ober-Ostu a siłami „reprezentującymi” drugą stronę frontu. 2 grudnia 1917 r. w Brześciu Litewskim rozpoczęły się między państwami centralnymi a bolszewikami negocjacje dotyczące warunków rozejmu. Na czele delegacji bolszewickiej stał Adolf Joffe, który w trakcie obrad przedstawił sowieckie propozycje pokojowe. Dnia 9 (22) grudnia 1917 r. w oświadczeniu delegacji sowieckiej na pierwszym posiedzeniu konferencji w Brześciu o propozycjach pokojowych rządu sowieckiego zaproponowano w punkcie trzecim: ,grupom narodowym, nieposiadającym do wojny samodzielności politycznej, gwarantuje się możliwość decydowania o swojej przynależności do tego czy innego państwa lub też niepodległości ustanawianej drogą referendum"21. Istotniejsze były propozycje zgłoszone 14 (27) grudnia 1917 r. w komisji politycznej konferencji pokojowej w sprawie ewakuacji wojsk z krajów okupowanych. Zawierały one m.in. żądanie pokoju bez aneksji. Rosja miała ewakuować swoje wojska z terenów Austro-Węgier, Turcja z Persji, a państwa centralne z zajętych przez siebie Polski, Litwy, Kurlandii i okręgów państwowych Rosji. Na tych terenach mogły stacjonować jedynie wojska „narodowe” lub lokalne milicje. W przyjętych 15 (28) grudnia warunkach rozejmu stwierdzono o pozostaniu wojsk na dotychczas zajmowanych pozycjach (ważnym uzupełnieniem było stwierdzenie, że żaden oddział nie mógł zostać przeniesiony na inny front). Termin rozpoczęcia negocjacji pokojowych został określony na 14 stycznia 1918 r. Ich miejscem miał być Brześć Litewski.

Aspiracje białoruskie miały zostać zaprezentowane w Brześciu przez delegację Rady Zjazdu (Kongresu) w skład której weszli Szymon Rak-Michajłowski, Iwan Sierada i Alaksandr Cwikiewicz. Wśród postulatów znalazło się oczekiwanie szerokiej autonomii w ramach państwa rosyjskiego, przyszła odbudowa gospodarcza ziem białoruskich i wypłata odszkodowań z funduszy międzynarodowych. Mimo pewnego poparcia Rady przez delegację ukraińską Białorusini nie zostali dopuszczeni do obrad jako strona, choć mogli uczestniczyć w ich części jako obserwatorzy. W samym Brześciu negocjacje pokojowe utknęły w miejscu, co związane było przede wszystkim z zajęciem stanowiska bolszewickiego po przybyciu i objęcia kierownictwa nad delegacją sowiecką przez Lwa Trockiego. Wobec tego, jak również w związku z podpisaniem przez Ukraińską Republikę Ludową 9 lutego pokoju z Państwami Centralnymi, głównodowodzący wojskami Ober-Ostu gen. Max Hoffman podjął decyzję o wznowieniu ofensywy. Postępowała ona błyskawicznie wobec braku oporu wojsk rosyjskich. Po pojawieniu się pierwszych pogłosek o postępach wojsk niemieckich bolszewicy 18 lutego ewakuowali

${ }^{21}$ B. Chernev, Twilight of Empire: The Brest-Litovsk Conference and the Remaking of East-Central Europe. 1917-1918, Toronto-London 2017, s. 44-45. 
Mińsk, do którego kilka dni później wkroczyli Niemcy. Ich wejście wygasiło starcia między siłami polskimi, białoruskimi i rosyjskimi, jakie wybuchły w ograniczonym zakresie po wycofaniu się bolszewików. Wkrótce siły niemieckie opanowały wszystkie ziemie białoruskie.

\section{TRZY HRAMOTY KONSTYTUCYJNE - KU PROKLAMOWANIU NIEPODLEGLOŚCI}

W samym Mińsku jeszcze 19 lutego 1918 r. ukonstytuował się Ludowy Sekretariat na czele z Jazepem Waronką, Arkadziem Smoliczem i Kanstancinem Jezawitau, który ogłosił się „rządem Białorusi”, a 21 lutego przedstawiono pełny skład „rządu”22. Tego samego dnia Komitet Wykonawczy WRB wydał Pierwszą Hramotę Konstytucyjną ${ }^{23}$, w której duży nacisk położono na prawo narodu białoruskiego do samostanowienia, przy jednoczesnych gwarancjach swobód dla innych grup narodowych zamieszkujących Białoruś. W Hramocie zaakcentowany został apel o samoorganizację ludności białoruskiej w obliczu nadciągającej „niemieckiej okupacji”. Z pewnością nie wpłynęło to na właściwe relacje z niemieckimi władzami okupacyjnymi. W treści Pierwszej Hramoty skoncentrowano się na kwestiach społecznych, podnosząc konieczność obrony „zdobyczy rewolucji socjalnej”, natomiast pominięto kwestię niepodległości Białorusi czy choćby szerokiej autonomii. Wyjaśnienie tego stanowiska było stosunkowo proste i wiązało się prorosyjskim nastawieniem działaczy ze wschodnich części kraju. Nie należy też zapominać o rozpędzeniu Zjazdu pod pretekstem białoruskiego „nacjonalizmu”. Co prawda, wydarzenie to zostało potępione przez Radę Komisarzy Ludowych, wywołało też zdecydowaną reakcję Józefa Stalina, jednak od tego czasu wiele się zmieniło, a na samych bolszewikach istotne wrażenie wywołała faktyczna „utrata” Ukrainy po podpisaniu przez jej delegatów pokoju 9 lutego ${ }^{24}$. Wobec niemieckiej ofensywy trudno było zakładać, że Petersburg (już po podpisaniu pokoju 7 marca bolszewicy ewakuowali stolicę do Moskwy) przychylnym okiem spojrzy na „tendencje separatystyczne”. Tym bardziej że jeszcze 30 stycznia przy Ludowym Komisariacie ds. Narodowości powstał Białoruski Komisariat Narodowy, co stanowiło sygnał, że bolszewicy nie zamierzali uwzględniać stanowiska białoruskich „lokalnych” elit politycznych. W perspektywie kolejnej tury pokojowych negocjacji niemiecko-bolszewickich rezygnacja z dalekosiężnych aspiracji

22 Vide szerzej D. Michaluk, Białoruska Republika Ludowa 1918-1920. U podstaw białoruskiej państwowości, Toruń 2010, s. 280-283. Skład gabinetu: J. Waronka (przewodniczący Ludowego Sekretariatu i ludowy sekretarz spraw zagranicznych), P. Badunowa (ludowy sekretarz opieki), G. Biełkind (ludowy sekretarz finansów), J. Bialewicz (ludowy sekretarz sprawiedliwości), T. Hryb (ludowy sekretarz rolnictwa), M. Gutman (ludowy sekretarz spraw żydowskich), K. Jezawitau (ludowy sekretarz spraw wojskowych), P.U. Złobin (ludowy sekretarz do spraw rosyjskich), A. Karacz (ludowy sekretarz poczty i telegrafu), P. Kraczeuski (ludowy sekretarz kontroli), I. Mokrejew (ludowy sekretarz spraw wewnętrznych), W. Redźka (ludowy sekretarz łączności), I. Sierada (ludowy sekretarz gospodarki), A. Smolicz (ludowy sekretarz oświaty), W. Zacharka (skarbnik), L. Zajac (sekretarz).

${ }^{23}$ Першая Ў стаўная Грамата да Народаў Беларусі (skan oryginału), <http://www.radabnr.org/ usthramaty/hramata1/>, dostęp 20 IV 2018.

${ }^{24}$ J. Reginia-Zacharski, Sprawa ukraińska w polityce Wielkiej Brytanii w latach 1917-1923, Toruń 2004, s. 68. 
narodowościowych w Pierwszej Hramocie okazała się dość istotnym błędem. W traktacie pokojowym z 3 marca, kończącym wojnę między Rosją Sowiecką a Państwami Centralnymi, znalazł się zapis o nieuznawaniu przez sygnatariuszy „nowych państw”, które po ratyfikacji traktatu brzeskiego chciałyby proklamować własną niepodległość. Inne klauzule przewidywały, że po wycofaniu się wojsk Ober-Ostu (po spełnieniu określonych warunków) białoruskie ziemie miały zostać podzielone między Rosję a Ukraińską Republikę Ludową.

Po zajęciu Mińska przez Niemców stosunki między działaczami białoruskimi a władzami wojskowymi nie układały się najlepiej. 24 lutego przedstawiciele Sekretariatu spotkali się z komendantem wojsk niemieckich, aby zapewnić o lojalnej współpracy, jednak następnego dnia działacze białoruscy zostali usunięci z siedziby (która została zajęta na potrzeby niemieckiej orkiestry wojskowej), z budynku usunięto biało-czerwono-białą flagę, a środki finansowe Sekretariatu zostały skonfiskowane. Kanstancin Jezawitau otrzymał formalny zakaz formowania białoruskiej armii, co w praktyce oznaczało fiasko całej koncepcji utworzenia białoruskiego wojska. Co prawda, po kilku dniach sytuacja uległa pewnemu unormowaniu i 28 lutego Niemcy wyrazili zgodę na wznowienie działalności Ludowego Sekretariatu (już w innej siedzibie), jednak wzajemne stosunki były naznaczone sporą nieufnością. Unormowanie relacji z władzami okupacyjnymi, a przede wszystkim podpisanie niekorzystnego z punktu widzenia interesów białoruskich traktatu brzeskiego, zradykalizowało Komitet Wykonawczy Rady Zjazdu Wszechbiałoruskiego. Efektem tego było ogłoszenie 9 marca Drugiej Hramoty Konstytucyjnej ${ }^{25}$. W dokumencie proklamowano powstanie Białoruskiej Republiki Ludowej „W granicach rozmieszczenia i liczebnej przewagi narodu białoruskiego" ${ }^{26}$. Dokładne granice ani obszar państwa nie zostały dookreślone. Zapowiadano przeprowadzenie wolnych i demokratycznych wyborów do Sejmu Ustawodawczego, choć nie precyzowano żadnych terminów ${ }^{27}$. Do czasu jego ukonstytuowania się władza ustawodawcza miała być sprawowana przez Radę Wszechbiałoruskiego Zjazdu, a władza wykonawcza miała się znajdować w rękach Ludowego Sekretariatu ${ }^{28}$. W Hramocie znalazły swoje miejsce zasady demokratyzmu i wolności słowa, przekonań, swobód religijnych i etnicznych, jak też gwarancje wolności osobistej i majątkowej. Przewidywano upaństwowienie lasów, wód i zasobów naturalnych oraz uwłaszczenie wszystkich

25 Другая Ўстаўная Грамата да народаў Беларусі (skan oryginału, <http://www.radabnr.org/usthra maty/hramata2/>, dostęp 23 IV 2018.

26 „Беларусь у рубяжох расьсяленьня і лічэбнай перавагі беларускага народу абвяшчаецца Народнай Рэспублікай”.

27 „Асноўныя законы Беларускай Народнай Рэспублікі зацьвердзіць Устаноўчы Сойм Беларусі, скліканы на асновах агульнага, роўнага, простага, патаёмнага і прапарцыянальнага выбарчага права, не зважаючы на род, народнасьць і рэлігію”.

${ }^{28}$ „Да часу, пакуль зьбярэцца Устаноўчы Сойм Беларусі, заканадаўчая ўлада ў Беларускай Народнай Рэспубліцы належыць Радзе Усебеларускага Зьезду дапоўненай прадстаўнікамі нацыянальных меншасьцяу Беларусі. Спаўняючая і адміністрацыйная ўлада ў Беларускай Народнай Рэспубліцы належыць Народнаму Сакратарыяту Беларусі, які назначаецца Радаю Зьезду і перад ёю трымае адказ". 
pracujących na roli ${ }^{29}$. Istotnym fragmentem, któremu poświęcono wiele uwagi, była kwestia równouprawnienia narodowości zamieszkujących ziemie białoruskie. Zakres swobód posunięty był tak daleko, że nie przewidywano nawet nadrzędności języka białoruskiego, gwarantując równe traktowanie dla wszystkich języków używanych na Białorusi $i^{30}$.

Ostatecznie Rada Wszechbiałoruskiego Zjazdu została przemianowana na Radę Białoruskiej Republiki Ludowej (Radę Republiki), która przejęła uprawnienia wszelkich rad, w tym przede wszystkim wileńskiej. Zaowocowało to pojawieniem się wielu działaczy tych kręgów w Mińsku. Wkrótce istotną rolę zaczęli odgrywać bracia Anton i Iwan Łuckiewiczowie. Wileńskie środowiska Białorusinów były zdecydowanie bardziej radykalnie nastawione narodowościowo, a włączenie się ich do głównego nurtu spowodowało wyraźne przechylenie się nastrojów w kierunku tendencji „niepodległościowych”. Grupa „wileńska” nadawała ton atmosferze II sesji Rady Republiki, której kulminacja przypadło na noc z 24 na 25 marca. Ostatecznie 25 marca 1918 r. około godziny 6 rano została przyjęta uchwała w sprawie proklamowania niepodległości Białoruskiej Republiki Ludowej. Tego samego dnia została ona ogłoszona jako Trzecia Hramota Konstytucyjna $^{31}$. Wywołało to spore kontrowersje w samej Radzie oraz w łonie Sekretariatu. Część eserów (socjaliści-rewolucjoniści) i przedstawicieli Bundu głosowała przeciwko proklamacji. Pozostałe socjalistyczne organizacje żydowskie wstrzymały się od głosu. O ile Żydzi zdecydowali się na pozostanie w Radzie Republiki, to eserzy opuścili ją bezpośrednio po głosowaniu. Radę oraz Sekretariat opuścił m.in. Paweł Żłobin.

W dokumencie stwierdzano, „Białoruska Republika Ludowa obwołuje się niezależnym i wolnym państwem" ${ }^{32}$, w granicach byłych rosyjskich guberni: mińskiej, mohylewskiej, grodzieńskiej, witebskiej, smoleńskiej oraz zamieszkałych w większości przez Białorusinów części guberni wileńskiej i czernihowskiej ${ }^{33}$. Hramota proklamowała unieważnienie wszelkich postanowień traktatu brzeskiego, które zostały podjęte bez „woli narodu białoruskiego". Jednocześnie wyrażano wolę podjęcia negocjacji pokojowych ze wszystkimi sygnatariuszami traktatu, które doprowadziłyby do podpisania „umów pokojowych" respektujących wolę Białorusinów. W zakresie dotyczącym praw Białoruskiej Republiki Ludowej [dalej: BRL] utrzymywano w mocy postanowienia Drugiej Hramoty.

29 „У рубяжох Беларускай Народнай Рэспублікі права ўласнае ўласнасьці на зямлю касуецца. Зямля перадаецца бяз выкупу тым, што самі на ёй працуюць. Лясы, вазёры і нутро зямлі абвяшчаюцца ўласнасьцю Беларускай Народнай Рэспублікі”.

30 „У рубяжох Беларускай Народнай Рэспублікі ўсе народы маюць права на нацыянальна-пэрсанальную аўтаномію; абвяшчаецца роўнае права ўсіх моваў народаў Беларусі”.

31 Трэцяя Ўстаўная Грамата Рады Беларускай Народнай Рэспублікі (skan oryginału), <http://www. radabnr.org/usthramaty/hramata3/>, dostęp 23 IV 2018.

32 „Ад гэтага часу Беларуская Народнай Рэспубліка абвяшчаецца Незалежнаю і Вольнаю Дзяржавай. Самі народы Беларусі ў асобе Ўстаноўчага Сойму пастановяць аб будучых дзяржаўных зьвязях Беларусі”.

33 „Беларуская Народная Рэспубліка павінна абняць усе землі, дзе жыве і мае лічбенную перавагу беларускі народ, а ласьне: Магілеўшчыну, беларускія часьці Меншчыны, Гарадненшчыны (з Горадняй, Беластокам і інш.), Віленшчыны, Віцебшчыны, Смаленчшыны і сумежных часьцяу суседніх губэрняў, заселеных беларусамі". 
W aspekcie międzynarodowym warto podkreślić dwa elementy związane z proklamowaniem niepodległości i ogłoszeniem Trzeciej Hramoty. Niepodległość BRL była równoznaczna z upodmiotowieniem ziem białoruskich i zerwaniem związków z Sowiecką Rosją, aspiracje terytorialne proklamowanego państwa były sprzeczne z umową międzynarodową, którą stanowił traktat brzeski. O ile przyszły konflikt z Ukraińską Republiką Ludową nie wydawał się szczególnie niebezpieczny dla aspiracji białoruskich, to już relacje z bolszewikami rosyjskimi zostały naznaczone wrogością. Przy okazji (o czym napisałem wcześniej) wśród samych działaczy białoruskich doszło do wyraźnego podziału względem scenariuszy ułożenia sobie relacji z Rosją. Ponadto Trzecia Hramota została przyjęta i ogłoszona bez żadnych konsultacji z Niemcami, co natychmiast doprowadziło do doraźnego konfliktu - Rada Republiki i Sekretariat zostały rozpędzone. Dopiero po kilku dniach władze okupacyjne uznały Radę za reprezentację narodową, a Ludowy Sekretariat za jej organ. Niemniej niemiecka akceptacja obszaru działań Sekretariatu ograniczyła to pole do oświaty, kultury i spraw socjalnych ${ }^{34}$.

\section{PROBLEMY POLITYCZNE BIALORUSKIEJ REPUBLIKI LUDOWEJ} (MARZEC-GRUDZIEŃ 1918 R.)

Warto odnotować fakt, że w efekcie Drugiej Hramoty w gabinecie Jazepa Waronki byli obecni właściwie wyłącznie socjaliści. Poza „głównym nurtem” rządowym znalazło się wówczas wiele środowisk, które usiłował skonsolidować Roman Skirmunt. To kolejna ciekawa postać - Polak dla Białorusinów i Białorusin dla Polaków. W marcu z jego inicjatywy powstało Mińskie Przedstawicielstwo Białoruskie, które notabene utrzymywało dość ożywione kontakty z Mińską Dumą Miejską. Ta ostatnia, choć poparła Drugą i Trzecią Hramotę Konstytucyjną, zachowywała daleko idącą ostrożność wobec radykalnych propozycji społecznych. W tym punkcie stanowisko Dumy Miejskiej było zresztą zbieżne z poglądami Skirmunta, który na plan pierwszy wysuwał budowanie państwa białoruskiego, stając w pewnej opozycji do Waroki, akcentującego przede wszystkim kwestie rewolucji społecznej. Przyjazd,,wilniuków” z Łuckiewiczami na czele doprowadził do wypracowania wspólnego stanowiska, jednak napięcie w Radzie Republiki utrzymywało się nadal. Pozycji Waronki nie wzmocnił również skandal finansowy, w którym oskarżano go defraudację 150 tys. rubli przesłanych przez ukraińską Centralną Radę ${ }^{35}$.

Działacze białoruscy przystąpili do wytężonej pracy na rzecz budowania organów terenowych władz państwowych BRL oraz zrębów struktur samorządowych. Niemieckie władze okupacyjne z dużą rezerwą podchodziły do państwowotwórczych działań kręgów białoruskich, niemniej aktywność oświatowa, kulturalna i społeczna nie budziły ich zastrzeżeń. W kwietniu 1918 r. ta aktywność nabrała szczególnego rozmachu. Udało się otworzyć kilkadziesiąt szkół podstawowych i ponadpodstawowych. Dość żywiołowo tworzyły się zalążki wszechnic, w planach pozostawało powołanie uniwersytetu

34 D. Michaluk, Białoruska Republika Ludowa..., s. 238-239.

35 Istotnie z Ukraińskiej Republiki Ludowej nadeszło 150 tys. rubli jako pierwsza transza pożyczki udzielonej BRL. Pieniądze te trafiły bezpośrednio do J. Waronki i zniknęły. J. Gierowska-Kałłaur, Stanowisko Rady... 
białoruskiego ${ }^{36}$. Na prowincji powstawały organizacje i koła krzewienia kultury białoruskiej, instytucje samopomocowe i spółdzielcze. Wiele wysiłku wkładano również w animację sztuki białoruskiej - udało się nawet utworzyć białoruski teatr narodowy. Oczywiście efekty tych poczynań nie były symetryczne na całym terytorium Białorusi - większe sukcesy odnotowywano na wschodzie kraju. Na zachodnich obszarach, do których aspirowała BRL, występowały dość spore trudności. Obok tradycyjnej „konfrontacji” z wpływami polskimi, białoruscy aktywiści rywalizowali z Ukraińcami i Litwinami. Było to typowe dla regionów ,pogranicza” z niejednorodnymi wpływami kulturowo-politycznymi ${ }^{37}$. Szczególnie dotkliwe okazały się dla BRL relacje z administracją Ukraińskiej Republiki Ludowej (również pod rządami hetmana Pawły Skoropadśkoho), która na przyznanych jej traktatem brzeskim obszarach Polesia organizowała własne instytucje ${ }^{38}$. „Konkurencja” zewnętrzna nie była jedynym problemem — część ludności miejscowej w zachodnich obszarach ziem białoruskich, która z dużą nieufnością odnosiła się do przedstawicieli BRL.

Dla budowania poczucia tożsamości narodowej i państwowej Białorusinów istotne znaczenie miały oczywiście symbole państwowe BRL. O fladze pisałem już wcześniej w kontekście jej zrzucenia z budynku Ludowego Sekretariatu przez wchodzących do Mińska Niemców. Biało-czerwono-biała flaga została najprawdopodobniej zaprojektowana bezpośrednio po rewolucji lutowej przez Klaudiusza Duż-Duszewskiego. W ten sposób nawiązywano do kokard noszonych wcześniej przez studentów białoruskich. W kontekście heraldycznym właściwsze wydaje się wskazanie źródła tej kolorystyki w godle Wielkiego Księstwa Litewskiego - Pogoni. Ostatecznie w czasach Władysława Jagiełly ukształtowała się finalna formuła godła ${ }^{39}$ — jeździec na białym koniu $\mathrm{z}$ tarczą $\mathrm{z}$ krzyżem litewskim na lewym ramieniu, $\mathrm{z}$ mieczem wzniesionym $\mathrm{w}$ prawej ręce, na polu czerwonym ${ }^{40}$. Pogoń jako herb Białoruskiej Republiki Ludowej została oficjalnie przyjęta wraz z proklamowaniem niepodległości. Sama flaga używana była z pewnością w 1917 r., zresztą stała się obiektem dość burzliwych wydarzeń: w grudniu 1917 r. podczas obrad I Zjazdu Wszechbiałoruskiego, jeden z delegatów — Łotysz — miał powiedzieć: „Zabierzcie tę trójkolorową szmatę”, co wywołało bardzo żywiołową reakcję pozostałych delegatów. Interpretacje znaczenia kolorystyki flagi państwowej bywały zresztą różne - według niektórych nawiązywała ona do krzyża św. Jerzego, inni wskazywali zbieżność ze stereotypem wyglądu chłopa białoruskiego: „Białe

${ }^{36}$ H. Głogowska, Między autotelicznym rozwojem a politycznym sterowaniem — kultura białoruska w okresie międzywojennym, [w:] Białoruś w XX stuleciu. W kręgu kultury i polityki, red. D. Michaluk, Toruń 2007, s. 610.

37 С. Токць, Беларуская інтэлігенцыя ў нацыянальным руху ў першай палове XX cт., [w:] Biatoruś w XX stuleciu. W kręgu kultury i polityki Przebieg granicy między Białoruska Republika Ludowa a Ukraińska Republika Ludowa w koncepcjach ukraińskich i białoruskich działaczy narodowych $w$ latach 1918-1919 - przedstawienia kartograficzne, red. D. Michaluk, Toruń 2007, s. 119-121.

38 Vide szerzej D. Michaluk, Przebieg granicy między Białoruska Republika Ludowa a Ukraińska Republika Ludowa w koncepcjach ukraińskich i białoruskich działaczy narodowych w latach 1918-1919 - przestawienia kartograficzne, [w:] Białoruś w XX stuleciu..., s. 247-268.

${ }^{39}$ Część badaczy wskazuje na czasy nieco wcześniejsze — Litwę Olgierda.

${ }^{40}$ Między „wersją” białoruską a litewską występują pewne różnice w kolorystyce detali. 
spodnie, biała koszula, biała świtka, przepasana czerwonym pasem - oto sylwetka Białorusina”41. W innych interpretacjach wskazywano „pot, krew i łzy”42. Przyjęcie ostatniego z symboli BRL — hymnu, którym został „Żołnierski marsz” („Ваяцкі марш”, tekst Makar Kraucou, muzyka Uładzimier Terauski) — przypadło na czas, gdy władze BRL znalazły się na uchodźstwie. Sam utwór powstał późną jesienią 1919 r. Oczywiście podczas wielu uroczystości narodowych w 1917 i 1918 r. wykonywano wiele różnych utworów śpiewanych jako pieśni narodowe, jednak żadna nie zyskała rangi hymnu.

Wyjątkowo problematyczna okazała się kwestia granic BRL. Żadna z trzech Hramot Konstytucyjnych nie precyzowała terytorialnych aspiracji narodowych kół białoruskich. Po części wynikało to ze względów taktycznych. W pierwszym okresie, gdy dominowało przekonanie utrzymania ścisłych związków z Rosją (a właściwie pozostanie w jej granicach) wysuwanie postulatów terytorialnych uznawano za niewskazane. Pod okupacją niemiecką sytuacja pozostawała równie trudna. Trzeba pamiętać, że państwa centralne były sygnatariuszami dwóch traktatów pokojowych $-z$ Ukrainą i Rosją Sowiecką - które regulowały kwestie graniczne. Sami Niemcy do białoruskich aspiracji odnosili się z dużą rezerwą, co nie tworzyło właściwej atmosfery dla eksplikowania programów terytorialnych. Jeśli chodzi o Ukraińską Republikę Ludową trzeba zauważyć, że mimo przyjaznych stosunków właśnie kwestie granic między URL i BRL należały do bardzo delikatnych ${ }^{43}$. Nie mniejsze problemy pojawiały się w relacjach z Litwą i Polską, a w mniejszym stopniu $\mathrm{z}$ Łotwą ${ }^{44}$. Podstawą stanowiska białoruskiego w wielostronnych rozmowach delimitacyjnych stał się „Opis granic Białoruskiej Republiki Ludowej”. Jednak dopiero na przełomie 1918 i 1919 r. Rada Republiki na potrzeby przyszłej konferencji pokojowej opracowała zwartą i obowiązującą koncepcję przebiegu granic, którą ilustrowała wydana na początku 1919 r. w Berlinie kolorowa Карта Беларускай Народнай Рэспублікі (drugi tytuł w języku francuskim: Carte de la République Démocratique Blanche-Ruthènienne), która już dość dokładnie przedstawiała aspiracje Republiki ${ }^{45}$. Niemniej trzeba zauważyć, że 18 stycznia 1919 r., gdy rozpoczynała się konferencja pokojowa w Paryżu, ziemiami białoruskimi władali bolszewicy, a narodowe przedstawicielstwa BRL zostały zmuszone do ewakuacji (początkowo do Grodna pod opiekę niemiecką, następnie do Kowna). Niepodległa Białoruś istniała jako idea, jednak „realne” możliwości jej realizacji zostały na dekady zamknięte.

Po proklamowaniu niepodległości (mimo trudnych warunków) życie polityczno-społeczne Białorusi nabrało istotnego przyśpieszenia. Na przełomie marca i kwietnia 1918 r. Ludowy Sekretariat (rząd) pod kierownictwem Waronki prowadził szerokie konsultacje na rzecz „scalenia” istniejących organów polityczno-społecznych w terenie w administrację państwową. Zabiegano też o tworzenie nowych instytucji. „,Tymczasowy

${ }^{41}$ Cyt. za O. Łatyszonek, Symbolika państwowa Białoruskiej Republiki Ludowej, [w:] Białoruś w XX stuleciu..., s. 217.

42 Ibidem, s. 218.

43 D. Michaluk, Przebieg granicy między Białoruską Republiką Ludową.., s. 247-268; idem, Białoruska Republika Ludowa..., s. 255-258.

44 D. Michaluk, Białoruska Republika Ludowa..., s. 260-262.

45 Ibidem, szczegółowe omówienie przebiegu granic, s. 264-266. 
nakaz dla terenowych rad białoruskich" z 29 kwietnia miał na celu ujednolicenie procesu wyłaniania, jak też funkcjonowania organów terenowych. Warto odnotować, że w dokumentach $\mathrm{z}$ tego okresu (wiosna-lato) zauważano pojawianie się silnych tendencji wrogich organom BRL, np. tak się działo na obszarach guberni wileńskiej i mohylewskiej. Na Polesiu często aktywność białoruska wchodziła w zderzenie z inicjatywami ukraińskimi. Jednak doniesienia z innych regionów z pewnością mogły napawać optymizmem. Co prawda, jeszcze 27 marca gabinet Waronki formalnie podporządkował sobie wszystkie instytucje urzędowe Białorusi, jednak w praktyce obszar działania Sekretariatu był ograniczony do aktywności społecznej i kulturalno-oświatowej. W dużej mierze działo się to za sprawą stanowiska niemieckich władz okupacyjnych. Paradoksalnie to właśnie one doprowadziły do rozszerzenia aktywności instytucji białoruskich. Możliwości działania Ludowego Sekretariatu i Rady Republiki ograniczały się do obszaru kontrolowanego przez Niemców i tu instytucje białoruskie stawały się naturalnym adresatem skarg ludności miejscowej na działania wojsk Ober-Ostu i obrońcą jej interesów, co dawało nowej administracji dodatkowy mandat ${ }^{46}$. Gabinet Waronki usiłował zdyskontować tę sytuację i poprawić własne relacje z Berlinem. W kwietniu na biurko kanclerza trafił obszerny memoriał przedstawiający dzieje Białorusi i białoruskiego ruchu narodowego. Usiłowano również wykorzystać kanały dyplomatyczne w Kijowie. Stanowisko władz niemieckich pozostawało nieugięte, gdyż obawiali się pogorszenia relacji z sowiecką Rosją i wzmożenia ich aktywności poprzez odejście od linii wyznaczonej w Brześciu Litewskim. Ponadto niemiecka administracja wojskowa uznawała (skądinąd słusznie) rząd białoruski za wyraźnie zdominowany przez socjalistów, co nie gwarantowało ograniczenia bolszewizacji kraju ${ }^{47}$.

Odpowiadając na zapotrzebowanie wynikające ze skomplikowanych stosunków z Niemcami, białoruscy działacze zdecydowali się na zmianę składu Rady Republiki i zmodyfikowanie gabinetu Waronki, do których weszli przedstawiciele umiarkowanych ugrupowań, przede wszystkim Mińskiego Przedstawicielstwa Białoruskiego (m.in. Roman Skirmunt). Ostatecznie obie instytucje zyskały zdecydowanie bardziej reprezentatywny charakter. Nie mniej pozostawanie Waronki na czele rządu podtrzymywało nieufność władz niemieckich. Próba zmiany tego nastawienia, jaką było wysłanie pod koniec kwietnia telegramu do cesarza Wilhelma II ${ }^{48}$, w którym szef rządu białoruskiego dziękował za wyzwolenie Białorusi spod władzy rosyjskiej, deklarował trwałość sojuszu z Rzeszą oraz prosił o poparcie dla Białoruskiej Republiki Ludowej, okazała się mało skuteczna. $Z$ pewnością jednym z powodów tej inicjatywy były wieści z Kijowa, gdzie przy poparciu Niemców doszło do obalenia Centralnej Rady i powołania do władzy hetmana Pawły Skoropadśkoho. Wskazuje na to choćby podkreślanie prośby „poparcia” BRL ${ }^{49}$. Reakcje politycznych środowisk białoruskich na wysłanie telegramu

46 D. Michaluk, Białoruska Republika Ludowa..., s. 289-290.

47 J. Turonek, Białoruś pod okupacją niemiecka, Warszawa 1993, s. 94.

48 Pod telegramem obok Waronki podpisali się przewodniczący Rady Republiki I. Siereda oraz członkowie Rady: P. Alesiuk, A. Ausianiuk, P. Kreczeuski, J. Losik i R. Skirmunt.

${ }^{49}$ Hetman Skoropadśkyj zmienił nazwę państwa „Państwo Ukraińskie”; vide J. Reginia-Zacharski, Sprawa ukraińska w polityce Wielkiej Brytanii w latach 1917-1923, Toruń 2004, s. 98-101. 
były zdecydowanie niechętne. Szczególnie ostro wystąpiły z krytyką ugrupowania lewicowe i tak silnie dotknięte przesunięciem w prawo składu Rady i Sekretariatu. Szczególnie ostro wypowiadano się przeciw Skirmuntowi. Ostatecznie doprowadziło to do wyraźnych pęknięć w łonie Rady Republiki i radykalizacji środowisk lewicowych.

Kryzys polityczny doprowadził 14 maja do upadku gabinetu Jazepa Waronki i powierzenia misji tworzenia Ludowego Sekretariatu Romanowi Skirmuntowi. Zmianie uległo też prezydium Rady Republiki, którego przewodniczącym został Jazep Losik. W exposé wygłoszonym 21 maja Skirmunt opowiadał się za wzmacnianiem instytucji BRL, akcentując konieczność bliskiej współpracy i dobrych stosunków z władzami niemieckimi. Istotne i kontrowersyjne zmiany w programie nowego rządu dotyczyły kwestii ziemskich — Skirmunt przychylał się do realizacji reformy rolnej zgodnej z zasadami prawa i poszanowaniem praw własności, która miałaby uwzględniać interesy chłopów, ale również właścicieli ziemskich. Silna opozycja wobec tego programu skłoniła Skirmunta 23 maja do złożenia na ręce przewodniczącego Rady Republiki dymisji, która jednak nie została przyjęta. W lipcu ukonstytuował się skład nowego gabinetu, przedstawiono też jego deklarację programową, która nie odbiegała od tez zawartych w exposé. Nowi ministrowie, którzy weszli w skład gabinetu, budzili kontrowersje, szczególnie wśród lewicowo nastawionych członków Rady Republiki. Paweł Aleksiuk - minister spraw zagranicznych, Radasłau Austrouski - minister rolnictwa, Stanisław Chrząstkowski - minister finansów, byli posądzani o skrajnie konserwatywne i propolskie poglądy. Całość gabinetu była z jednej strony przez socjalistów bojkotowana, z drugiej zaś - krytykowana za brak reprezentacji socjalistów. W takiej sytuacji rząd Skirmunta funkcjonował (a właściwie usiłował funkcjonować) w warunkach permanentnego kryzysu. Do jego kulminacji doszło latem. Jeszcze w lipcu usiłowano przedłużyć trwanie gabinetu, ogłaszając przerwę wakacyjną do 15 września. Jednak w odpowiedzi na to grupa socjalistów w Radzie Republiki skierowała memoriał do ludności Białorusi, a Waronka zdecydował się na utworzenie „Białoruskiego Rządu Tymczasowego”. W jego skład weszli członkowie dawnego Ludowego Sekretariatu kierowanego przez Waronkę. W sytuacji dwuwładzy Rada BRL zdecydowała o dymisji gabinetu Skirmunta i misję formowania nowego rządu powierzyła Iwanowi Sieredzie. Nowy rząd zatwierdzony został 22 lipca 1918 r. - 10 dni po utworzeniu nielegalnego gabinetu tymczasowego. Właściwie Sekretariat Sieredy zdominowany został przez ludzi Waronki i usiłował kontynuować program pierwszego Ludowego Sekretariatu. Istotne wzmożenie aktywności zaznaczyło się na polu dyplomatycznym - Białorusini usiłowali zagwarantować sobie większe poparcie władz niemieckich — tym razem próbując korzystać z pośrednictwa ukraińskiego. Rządy hetmańskie okazały się jednak wstrzemięźliwe. Mimo entuzjastycznych deklaracji Dmytro Doroszenki ${ }^{50}$, ukraińskiego ministra spraw zagranicznych, właściwie nie udało się osiągnąć niczego więcej niż słowne deklaracje poparcia. Sytuacja Białorusinów skomplikowała się w sierpniu w związku z ratyfikacją traktatu brzeskiego. Trwająca cały wrzesień i część października białoruska ofensywa dyplomatyczna nie przyniosła wymiernych efektów. Wobec tego Rada Republiki w początkach

50 Д. Дорошенко, Мої спомини про недавнє-минуле (1914-1918), частина 2, Львів 1923, s. 30. 
października odwołała Sieredę i cały gabinet. Nowym premierem został 12 października Anton Łuckiewicz, który jednak urząd objął na początku listopada 1918 r. po powrocie z negocjacji w Kijowie. Tym razem zrezygnowano z nazwy „Ludowy Sekretariat” na rzecz „Rady Ludowych Ministrów BRL” (Rada Ministrów BRL). Zadania, kompetencje i kształt rządu określone zostały na posiedzeniu Rady Republiki 11 listopada ${ }^{51}$.

Jednak w tym czasie sytuacja geopolityczna uległa radykalnej zmianie. Drugiego listopada $1918 \mathrm{r}$. Niemcy poprosiły o rozejm, który został podpisany w godzinach porannych 11 listopada (wszedł w życie około godziny 11). W odniesieniu do ziem białoruskich istotne postanowienia dotyczyły unieważnienia traktatu brzeskiego (art. XII) oraz wycofania wojsk niemieckich z (między innymi) obszarów dawnego Imperium Rosyjskiego $^{52} .13$ listopada Rosja sowiecka uznała nieważność traktatów brzeskich, a kilka dni później ruszyła bolszewicka ofensywa na zachód. Władze BRL zdawały sobie sprawę z narastającego zagrożenia. W pierwszej dekadzie listopada usiłowano organizować białoruskie oddziały wojskowe ${ }^{53}$, których celem miało być m.in. odparcie nacisku na Mińsk. Nie osiągnięto w tej materii większych sukcesów. Wycofujący się jeszcze w listopadzie z Białorusi Niemcy byli natychmiast zastępowani przez wojska i władze rosyjskich bolszewików, którzy właściwie nie napotykali żadnego oporu. Dość powiedzieć, że dla obrony stolicy nie udało się skierować żadnego białoruskiego oddziału. Ostatecznie 10 grudnia Mińsk został zajęty przez bolszewików. Wcześniej stolicę opuściły Rada Republiki i Rada Ministrów z premierem Łuckiewiczem. Organy władzy Białoruskiej Republiki Ludowej na krótko znalazły się w Wilnie i Grodnie (27 grudnia), które również zostały ewakuowane po opuszczeniu ich przez Niemców (oraz w obliczu rozwijającego się natarcia „czerwonej” Armii Zachodniej).

W 1919 r. Łuckiewicz reprezentował sprawę białoruską na konferencji pokojowej w Paryżu, jednak należy podkreślić, że delegacja nie zyskała uznania, a premier uzyskał zgodę na przyjazd do Francji dopiero w maju. Z perspektywy czasu trzeba uznać, że opuszczenie Mińska w symboliczny sposób zamknęło realne możliwości zbudowania państwowości białoruskiej. Emigracyjna aktywność instytucji i polityków BRL z pewnością odegrała istotną rolę, jednak należy ją raczej oceniać jako symboliczną niż realną.

\section{KONKLUZJE}

Podejmowane przez białoruskie elity od wiosny 1917 r. wysiłki na rzecz realizacji aspiracji narodowych, od autonomii w ramach Rosji do pełnej niepodległości i samodzielnego byty państwowego, ostatecznie zakończyły się fiaskiem. Zasadne wydaje się w takiej sytuacji pytanie o powody niepowodzenia. Niewątpliwie odpowiedź jest złożona. Przede wszystkim splot wydarzeń geopolitycznych okazał się niepomyślny dla idei budowy państwa białoruskiego. Od rewolucji lutowej w 1917 r. właściwie żaden z rządów rosyjskich nie odnosił się ze zrozumieniem wobec białoruskich aspiracji. Uwaga ta dotyczy także

${ }^{51}$ Rząd miał się składać z 14 ministrów (10 resortowych i czterech bez teki). Warto zauważyć, że nie udało się rozdzielenie władzy wykonawczej i ustawodawczej — dwóch członków spośród kierownictwa Rady Republiki znalazło się również w składzie ministrów.

52 A. Chwalba, Samobójstwo Europy. Wielka wojna 1914-1918, Kraków 2014, s. 590-601.

${ }^{53}$ O. Łatyszonek, Białoruskie formacje wojskowe 1917-1923, Białystok 1995, s. 128. 
bolszewików, którzy nawet deklarując wsparcie dla ruchów narodowowyzwoleńczych, czynili to koniunkturalnie. W rzeczywistości zwalczali je, gdy tylko nadarzała się możliwość. Wobec wrogości ze strony bolszewickiej białoruscy aktywiści spore nadzieje wiązali z Niemcami, którzy od marca 1918 r. opanowali większość kraju. Z pewnością nie była to łatwa współpraca - incydenty z użyciem siły ze strony wojskowych władz okupacyjnych nie należały wcale do rzadkości. Zupełnie inaczej też obie strony postrzegały zakres kompetencji możliwych do realizacji przez władze BRL. Jednak ostatecznie Rzesza Niemiecka przegrała wojnę i Białorusini, którzy z braku innej opcji politycznej właściwie do listopada 1918 r. deklarujący wolę współdziałania i trwałości sojuszu z Niemcami, znaleźli się politycznie w sytuacji katastrofalnej. Wspomniane przyczyny miały również wpływ na niemal zupełny brak rozwoju białoruskiego ruchu wojskowego. Wobec tego żadna $\mathrm{z}$ walczących stron nie postrzegała Białorusi jako - niewielkiej nawet - rezerwy siły zbrojnej. Dotyczyło to zarówno scenariuszy antyniemieckich, jak i antybolszewickich.

Uderzającą słabością białoruskich kadr politycznych było ich małe poparcie w terenie, można wręcz odnieść wrażenie, że BRL rozwijała się i funkcjonowała wyłącznie w większych miastach — głównie w Mińsku i Wilnie. Na prowincji idee narodowe były słabo zakorzenione, a białoruscy aktywiści niekiedy spotykali się wręcz z wrogością. Sprawiało to, że w istocie ruch narodowy nie miał solidnego zaplecza. „Teren” był bardzo podatny na bolszewizację, ale także głęboko rozwarstwiony społecznie. Ta niejednorodność widoczna była zresztą w samych elitach politycznych - w białoruskich instytucjach politycznych dochodziło do ostrych sporów politycznych. Nie może umknąć uwadze, że w okresie między proklamowaniem niepodległości (25 marca 1918 r.) a zajęciem Mińska przez bolszewików (10 grudnia 1918 r.) BRL były cztery rządy, jeśli nie liczyć „tymczasowego” rządu J. Waronki.

Podsumowując, można pokusić się o uwagę, że wyzwania stające w latach 1918-1919 przed zwolennikami idei niepodległości Białorusi, znacznie przerosły możliwości ruchu i zdolności organizacyjne. Wydaje się również, że tempo rozwoju wydarzeń oraz charakter wyzwań geopolitycznych znacznie przekraczały możliwości białoruskich elit. Ostatecznie 10 grudnia $1918 \mathrm{r}$. idea niepodległego państwa białoruskiego znalazła się ,na emigracji”, aby powrócić na ziemie białoruskie w pełnej odsłonie dopiero w roku 1991.

BIBLIOGRAFIA

PIŚMIENNICTWO

Batowski H., Rozpad Austro-Wegier 1914-1918, Wydawnictwo Literackie, Warszawa 1982.

Charaszkiewicz E., Przebudowa Europy Wschodniej. Fragmenty faktów z lat 1917-1924, „Niepodległość” 1974, t. 9.

Chernev B., Twilight of Empire: The Brest-Litovsk Conference and the Remaking of East-Central Europe. 1917-1918, University of Toronto Press, Toronto-London 2017, https://doi. org/10.3138/9781487513344.

Churchill W., The Unknown War. The Eastern Front 1914-1917, Charles Scribners Sons, London 1999.

Chwalba A., Samobójstwo Europy. Wielka wojna 1914-1918, Wydawnictwo Literackie, Kraków 2014. 
Czerniakiewicz A., „, Chto tam idzie?” Kryzys białoruskiego projektu kulturowego na progu pierwszej wojny światowej, [w:] Imperia, narody i społeczeństwa Europy Środkowej $i$ Wschodniej na progu pierwszej wojny światowej, red. A. Nowak, Centrum Polsko-Rosyjskiego Dialogu i Porozumienia, Warszawa 2016.

Fiedor K., Niemcy i Austria po I wojnie światowej w 1919 roku, [w:] Rok 1918 w Polsce $i$ w państwach sąsiednich. W osiemdziesięciolecie zakończenia pierwszej wojny światowej z perspektywy ślaskiej, red. L. Kuberski, M. Lis, Wydawnictwo Uniwersytetu Opolskiego, Opole 1998.

Gierowska-Kałłaur J., Stanowisko Rady Polskiej Ziemi Mińskiej w kwestii przyszłości Białorusi. Przyczyny zmiany stanowiska Komisji Litewskiej Tymczasowej Rady Stanu na jesieni 1918 roku, [w:] Białoruś w XX stuleciu. W kręgu kultury i polityki, red. D. Michaluk, Wydawnictwo Naukowe Uniwersytetu Mikołaja Kopernika, Toruń 2007.

Głogowska H., Między autotelicznym rozwojem a politycznym sterowaniem — kultura białoruska w okresie międzywojennym, [w:] Białoruś w XX stuleciu. W kręgu kultury i polityki, red. D. Michaluk, Wydawnictwo Naukowe Uniwersytetu Mikołaja Kopernika, Toruń 2007.

Kershaw I., Do piekta i z powrotem: Europa 1914-1949, Znak Horyzont, Kraków 2016.

Łatyszonek O., Białoruskie formacje wojskowe 1917-1923, Wydawnictwo Uniwersytetu w Białymstoku, Białystok 1995.

Łatyszonek O., Od Rusinów Białych do Białorusinów. U źródeł białoruskiej idei narodowej, Wydawnictwo Uniwersytetu w Białymstoku, Białystok 2006.

Łatyszonek O., Symbolika państwowa Białoruskiej Republiki Ludowej, [w:] Białoruś w XX stuleciu. W kręgu kultury i polityki, red. D. Michaluk, Wydawnictwo Naukowe Uniwersytetu Mikołaja Kopernika, Torun 2007.

Michaluk D., Białoruska Republika Ludowa 1918-1920. U podstaw białoruskiej państwowości, Wydawnictwo Naukowe Mikołaja Kopernika, Torun 2010.

Michaluk D., Przebieg granicy między Białoruska Republika Ludowa a Ukraińska Republika Ludowa $w$ koncepcjach ukraińskich $i$ białoruskich działaczy narodowych $w$ latach 1918-1919 - przestawienia kartograficzne, [w:] Biatoruś w XX stuleciu. W kręu kultury i polityki, red. D. Michaluk, Wydawnictwo Naukowe Uniwersytetu Mikołaja Kopernika, Torun 2007.

Moczulski L., Geopolityka. Potega w czasie i przestrzeni, Bellona, Warszawa 2010.

Pipes R., Rewolucja Rosyjska, Magnum, Warszawa 2006.

Radzik R., Kształtowanie się nowoczesnej białoruskości w XX stuleciu, [w:] Białoruś w XX stuleciu. W kręgu kultury i polityki, red. D. Michaluk, Wydawnictwo Naukowe Uniwersytetu Mikołaja Kopernika, Torun 2007.

Reginia-Zacharski J., Sprawa ukraińska w polityce Wielkiej Brytanii w latach 1917-1923, Wydawnictwo Adam Marszałek, Torun 2004.

Rok 1918 w Polsce $i$ w państwach sąsiednich. W osiemdziesięciolecie zakończenia pierwszej wojny światowej z perspektywy śląskiej, red.: L. Kuberski, M. Lis, Wydawnictwo Uniwersytetu Opolskiego, Opole 1998.

Токць С., Беларуская інтэлігенцыя ў нацыянальным руху ў першай палове XX ст., [w:] Białoruś w XX stuleciu. W kręgu kultury i polityki Przebieg granicy między Białoruska Republika Ludowa a Ukrainska Republika Ludowa w koncepcjach ukraińskich i białoruskich działaczy narodowych w latach 1918-1919 - przedstawienia kartograficzne, red. D. Michaluk, Wydawnictwo Naukowe Uniwersytetu Mikołaja Kopernika, Torun 2007.

Turonek J., Białoruś pod okupacją niemiecka, Książka i Wiedza, Warszawa 1993.

Дорошенко Д., Мої спомини про недавнє - минуле (1914-1918), частина 2, Львів 1923.

Другая Ўстаўная Грамата да народаў Беларусі (skan oryginału).

Першая Ўстаўная Грамата да Народаў Беларусі (skan oryginału).

Трэцяя Ўстаўная Грамата Рады Беларускай Народнай Рэспублікі (skan oryginału). 